\title{
Research on the modification of two traditional building materials in ancient China
}

\author{
Li Zuixiong ${ }^{1,3}$, Zhao Linyi ${ }^{1,3^{*}}$, Li Li $^{2}$ and Wang Jinua ${ }^{2}$
}

\begin{abstract}
Silicate material is one of the most typical materials used in both traditional and modern buildings. This paper presents a comparative analysis of two silicate materials (ginger nut and Aga soil) used in ancient Chinese buildings. The research suggests that ginger nut and Aga soil have similar chemical compositions and physical properties. After they are burned at a temperature of $700^{\circ} \mathrm{C} \sim 1400^{\circ} \mathrm{C}$, they will have a dual characteristic of hydraulicity and non-hydraulicity. As the temperature rises, the non-hydraulic constituent increases at first and then decreases, while the hydraulic constituent is increasing regularly. Their chemical composition and characteristics are similar to those of the "hydraulic lime" in Europe, and the modified ginger nut and Aga soil can be used for repairing and reinforcing the stone, earthen, brick and ceramic relics.
\end{abstract}

Keywords: Ancient buildings, Silicate, Material, Property

\section{Introduction}

In the late 1970s, a group of residential remains of the Yangshao Period were discovered at the Dadiwan site in Qin'an County, Gansu Province, China [1]. One of these discoveries is named as "original palace" (number F-901) in the archaeological world, and is the largest and top leveled residential site in prehistoric times. This site belongs to the middle Yangshao Period and was used for convocation, worshiping and religious ceremonies by tribes or tribe allies over 5000 years ago. When it was discovered, the site had a bright and clean house floor that was of exquisite workmanship. Preliminary research [2] indicates that the housing floor of the site was made by lightweight calcined Kunkur as aggregate and the powder of calcined ginger nut mixed with a small amount of laterite as bonding materials. After more than five thousand years, the compressive resistance of the floor is close to that of cement mortar No.100. Moreover, the remains of kilns for burning light weight concrete and ginger nut were discovered nearby the site. The research shows that the calcinated temperature of ginger nut could reach up to $900^{\circ} \mathrm{C}$ [3]. Ginger nut is a type of ginger stone (locally called as ginger nut) in quaternary loess and is composed

\footnotetext{
*Correspondence: dhzhly@163.com

${ }^{1}$ National Research Center for Conservation of Ancient Wall Paintings, Dunhuang 736200, China

${ }^{3}$ Dunhuang Academy, Dunhuang 736200, China

Full list of author information is available at the end of the article
}

of $60-80 \%$ calcium carbonate and $10-20 \%$ clay mineral. When ginger nut is calcinated at a temperature of $900^{\circ} \mathrm{C}$, it will produce $25.8 \% \beta-\mathrm{CaSiO}_{3}, 17.6 \% \mathrm{Ca}_{2} \mathrm{Al}_{2} \mathrm{SiO}_{7}$ and $33.9 \% \mathrm{CaO} . \beta-\mathrm{CaSiO}_{3}$ and $\mathrm{Ca}_{2} \mathrm{Al}_{2} \mathrm{SiO}_{7}$ are hydraulic binding materials, and $\mathrm{CaO}$ is a non-hydraulic binding material [4]. Therefore, the building materials of F-901 floor in which manmade hydraulic binding materials had been used can be called as the earliest "concrete" in the world, which is a miracle in the history of architecture [3].

Aga soil is another kind of silicate building material widely used in Tibet, and it is the siliceous limestone [5] that contains $70 \sim 93 \% \mathrm{CaCO}_{3}$ and $7 \sim 30 \% \mathrm{SiO}_{2}$. When Aga soil is used as building material for floor and house (roof), the unburned Aga soil with $40 \%$ in a diameter of $5.6 \mathrm{~mm}, 30 \%$ in a diameter of $2.6 \mathrm{~mm}$ and $30 \% 0.15 \mathrm{~mm}$ diameter will be made to pulp at the ratio of 0.32 water and then is rammed by a special stone pester. Until the grout completely becomes solid, it will be sanded first and then repeatedly polished with sheepskin and butter. This technique is called "ramming Aga" [6], and for centuries, this traditional material and building technology have been used to construct floors and roofs of temples in Tibet.

In Tibet, there are over one thousand temples that are very valuable cultural relics, such as the well-known Potala Palace, Norbulingka Summer Palace and Sakya Monastery. The Chinese government attaches great importance to the conservation of Tibetan cultural relics. 
In the last two decades, two large projects for the conservation and restoration of key relics including the Potala Palace and Sakya Monastery have been carried out [5,7]. The restoration work focuses on ancient buildings and murals, and the main kinds of deterioration are associated with Aga soil used in the roofs. In Tibetan, traditional materials for the roofs of the temple are unburned Aga soil that was crushed into the powder of $0.15 \mathrm{~mm}$ in diameters as "gelation" and it was mixed with proper amount of natural gum [6] to make mortar. But unburned Aga soil has low strength and poor weathering resistance but the property of chemical gelatinization. Influenced by the freezing and thawing cycles and the fluctuating temperature and humidity, the natural gum will quickly deteriorate and break. When the rain infiltrated through the cracks, wooden components will decay, fall apart or become leaning, causing subsequent deterioration, such as detachment, large-area loss, disruption and flaking, and thus terribly damaging the murals [7].

Therefore, the research and scientific modification of the two silicate materials in ancient Chinese buildings is very important for the restoration of stone, brick and pottery relics as well as the conservation of ancient Tibetan buildings and murals.

\section{The characteristic of ginger nut and aga soil}

Physical and mechanical properties of ginger nut and aga soil

The density and saturated water absorptivity of natural ginger nut and Aga soil were tested, and the samples in the size of $5 \mathrm{~cm} \times 5 \mathrm{~cm} \times 5 \mathrm{~cm}$ were made for the test of compressive strength (Table 1).

The chemical composition of ginger nut and Aga soil $\mathrm{X}$-fluorescence was used to analyze the chemical compositions of ginger nut and Aga soil (Table 2).

Mineral composition of ginger nut and aga soil

XRD was used to analyze the mineral composition of ginger nut and Aga soil (Table 3).

Table 1 Physical-mechanical properties of natural ginger nut and aga soil

\begin{tabular}{llll}
\hline Sample & Density/g $\mathbf{\mathbf { c m } ^ { - \mathbf { 3 } }}$ & $\begin{array}{l}\text { Coefficient of water } \\
\text { saturation/\% }\end{array}$ & $\begin{array}{l}\text { Compressive } \\
\text { strength/MPa }\end{array}$ \\
\hline $\begin{array}{l}\text { Ginger } \\
\text { nut }\end{array}$ & 2.52 & 5.58 & 55.78 \\
Aga soil 2.61 & 4.60 & 66.02 \\
\hline
\end{tabular}

Table 2 Chemical compositions of ginger nut and aga soil

\begin{tabular}{lllllll}
\hline Sample & $\mathrm{Na}_{\mathbf{2}} \mathbf{O}$ & $\mathbf{M g O}$ & $\mathrm{Al}_{\mathbf{2}} \mathbf{O}_{\mathbf{3}}$ & $\mathrm{SiO}_{2}$ & $\mathbf{P}_{\mathbf{2}} \mathrm{O}_{\mathbf{5}}$ & $\mathbf{K}_{\mathbf{2}} \mathbf{O}$ \\
\hline Ginger nut & 0.90 & 1.49 & 6.44 & 22.06 & 0.11 & 0.98 \\
Aga soil & 0.32 & 1.10 & 4.23 & 16.37 & 0.08 & 0.85 \\
\hline Sample & $\mathrm{CaO}$ & $\mathrm{Fe}_{\mathbf{2}} \mathrm{O}_{\mathbf{3}}$ & $\mathrm{TiO}_{2}$ & $\mathbf{M n O}$ & $\mathrm{CO}_{2}$ & Total \\
\hline Ginger nut & 36.82 & 2.07 & 0.35 & 0.08 & 28.60 & 99.90 \\
Aga soil & 41.87 & 0.87 & 0.21 & 0.02 & 34.07 & 99.99 \\
\hline
\end{tabular}

\section{The properties of calcined ginger nut and aga soil}

The influence of calcination temperature to products

When ginger nut and Aga soil are calcined at a high temperature, both the hydraulic material $\mathrm{CaO}$ and nonhydraulic material $\beta-\mathrm{CaSiO}_{3}$ and $\mathrm{Ca}_{2} \mathrm{Al}_{2} \mathrm{SiO}_{7}$ will be produced. And the calcination temperature directly affects the ratio of two kinds of the binding materials (Figures 1 and 2).

A semi-quantitative analysis had been done to the main products $\mathrm{CaO}, \beta-\mathrm{CaSiO}_{3}$ and $\mathrm{Ca}_{2} \mathrm{Al}_{2} \mathrm{SiO}_{7}$ in Ginger nut and Aga soil at different temperatures, and the curve lines showing how the products varied with temperature were made by comparing the analysis results (Figures 3 and 4).

Figures 1-4 indicate that at $700^{\circ} \mathrm{C}$ ginger nut produces $7.3 \% \quad \beta-\mathrm{CaSiO}_{3}$ and $5.2 \% \quad \mathrm{Ca}_{2} \mathrm{Al}_{2} \mathrm{SiO}_{7}$ with no $\mathrm{CaO}$ produced, and it produces $17.2 \% \mathrm{CaO}, 24.7 \%$ $\beta-\mathrm{CaSiO}_{3}$ and $16.3 \% \mathrm{Ca}_{2} \mathrm{Al}_{2} \mathrm{SiO}_{7}$ at $800^{\circ} \mathrm{C}$. When the temperature rises from $800^{\circ} \mathrm{C}$ to $1100^{\circ} \mathrm{C}$, the generating speed of $\mathrm{CaO}$ is obviously fast and it reaches up to the maximum $42.1 \%$, and this is the best temperature to produce $\mathrm{CaO}$. But the generating speed of $\beta-\mathrm{CaSiO}_{3}$ increases less obviously from $24.7 \%$ to $28.4 \%$ and the speed of $\mathrm{Ca}_{2} \mathrm{Al}_{2} \mathrm{SiO}_{7}$ from $16.3 \%$ to $19.15 \%$ is much less boviously. Thus this temperature range is not helpful for the generation of $\beta-\mathrm{CaSiO}_{3}$ and $\mathrm{Ca}_{2} \mathrm{Al}_{2} \mathrm{SiO}_{7}$. When the temperature rises from $1100^{\circ} \mathrm{C}$ to $1400^{\circ} \mathrm{C}$, the amount of $\mathrm{CaO}$ quickly drops from $42.1 \%$ to $16.7 \%$ because $\mathrm{CaO}$ takes part in the reaction to produce $\beta-\mathrm{CaSiO}_{3}$ and $\mathrm{Ca}_{2} \mathrm{Al}_{2} \mathrm{SiO}_{7}$. While $\beta-\mathrm{CaSiO}_{3}$ and $\mathrm{Ca}_{2} \mathrm{Al}_{2} \mathrm{SiO}_{7}$ are generated more quickly: $\beta-\mathrm{CaSiO}_{3}$ increases from $28.4 \%$ to $47.7 \%$ and $\mathrm{Ca}_{2} \mathrm{Al}_{2} \mathrm{SiO}_{7}$ increases from $19.1 \%$ to $35.5 \%$.

Table 3 XRD analysis results of ginger nut and aga soil

\begin{tabular}{lllll}
\hline Results & \multicolumn{4}{l}{ Analysis result of half quantitative/\% } \\
\cline { 2 - 5 } Sample & Quartz & Calcite & Feldspar & Clay \\
\hline Ginger nut & 12.6 & 61.8 & 10.9 & 14.7 \\
Aga soil & 10.5 & 75.1 & 11.2 & 3.0 \\
\hline
\end{tabular}




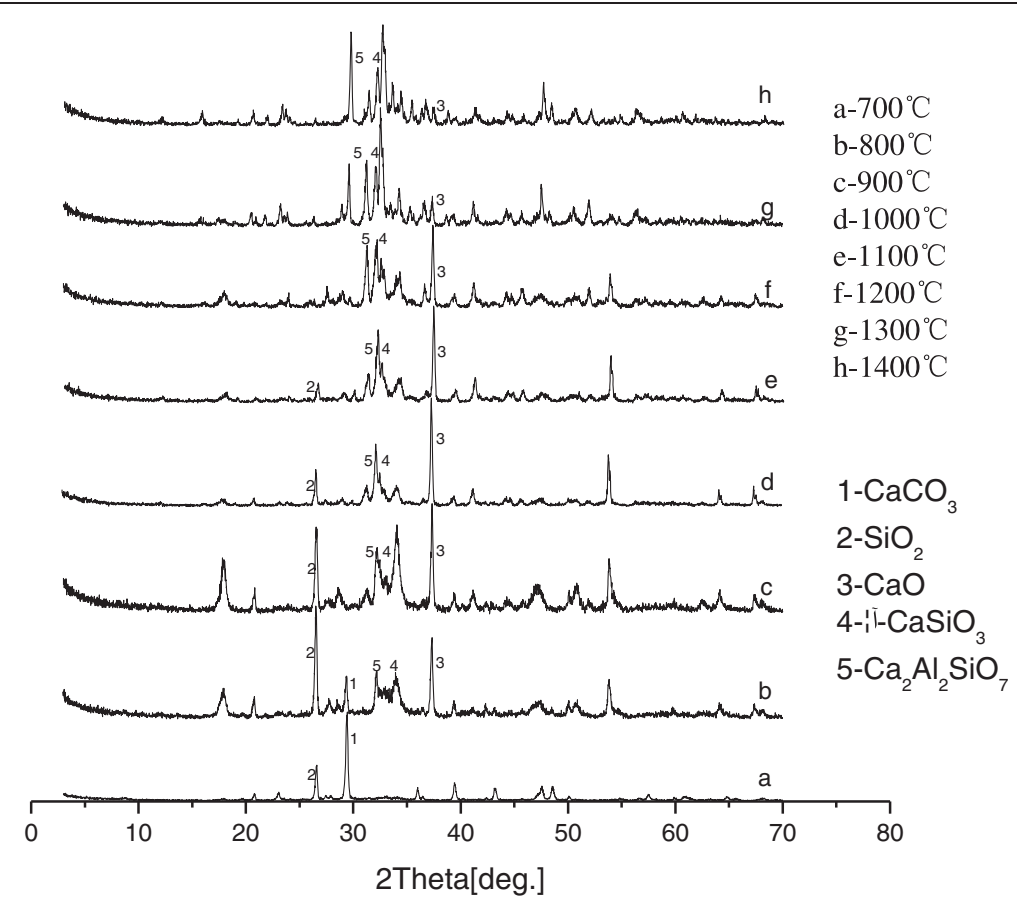

Figure $1 \mathrm{XRD}$ spectra of ginger nut calcined at $700^{\circ} \mathrm{C} \sim 1400^{\circ} \mathrm{C}$ and comparison of products $\left(1-\mathrm{CaCO}_{3} ; 2-\mathrm{SiO}_{2} ; 3-\mathrm{CaO} ; 4-\beta-\mathrm{CaSiO}_{3}\right.$; 5- $\left.\mathrm{Ca}_{2} \mathrm{Al}_{2} \mathrm{SiO}_{7}\right)$.

The condition of calcined Aga soil is similar to calcined ginger nut. At $700^{\circ} \mathrm{C}$ ginger nut produces $13.3 \% \beta-\mathrm{CaSiO}_{3}$ and $10.6 \% \mathrm{Ca}_{2} \mathrm{Al}_{2} \mathrm{SiO}_{7}$ with no $\mathrm{CaO}$ produced. At $800^{\circ} \mathrm{C}$, it produces $32.1 \% \mathrm{CaO}$, two times of that produced by ginger nut at the same temperature. The main reason is that Aga soil has a larger amount of $\mathrm{CaCO}_{3}$ than ginger nut and has half amount of $\mathrm{SiO}_{2}$ compared with ginger nut, which is useful for producing $\mathrm{CaO}$. At the temperature ranges from $800^{\circ} \mathrm{C}$ to $1100^{\circ} \mathrm{C}$ and from

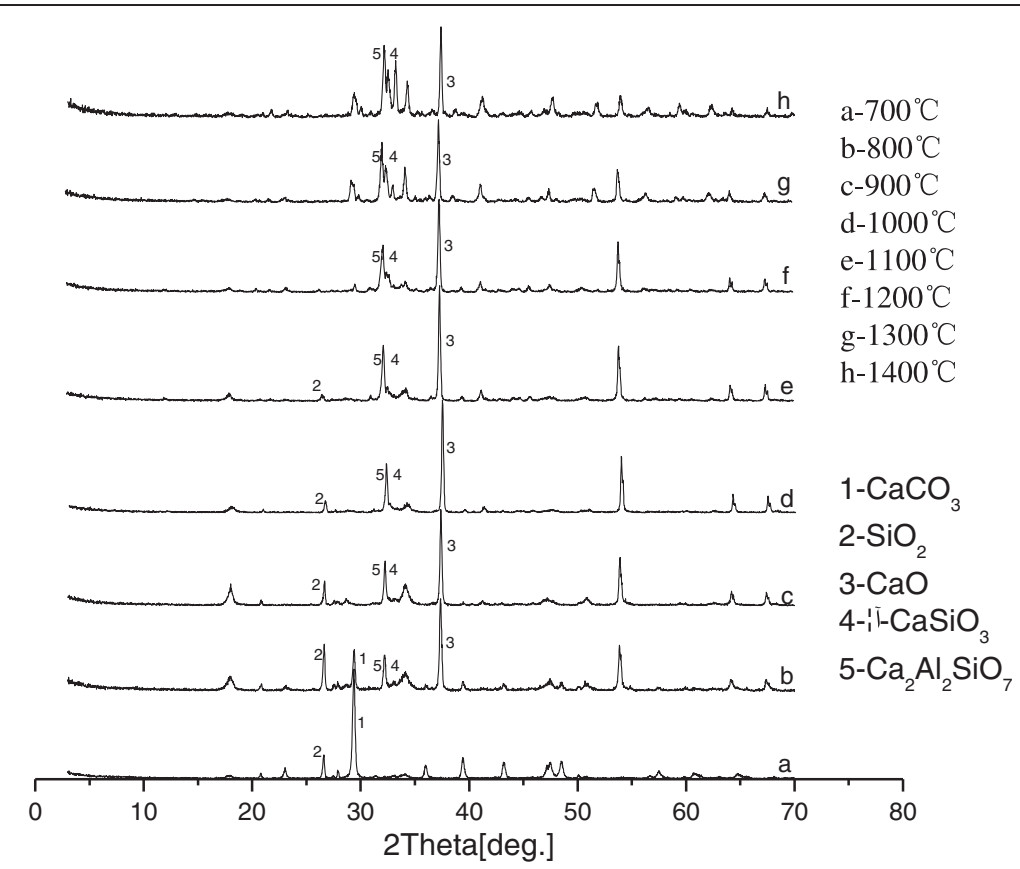

Figure $2 \mathrm{X}-\mathrm{RD}$ spectra of Aga soil calcined at $700^{\circ} \mathrm{C} \sim 1400^{\circ} \mathrm{C}$ and comparison of products $\left(1-\mathrm{CaCO}_{3} ; 2-\mathrm{SiO}_{2} ; 3-\mathrm{CaO} ; 4-\beta-\mathrm{CaSiO}{ }_{3}\right.$; 5- $\left.\mathrm{Ca}_{2} \mathrm{Al}_{2} \mathrm{SiO}_{7}\right)$. 


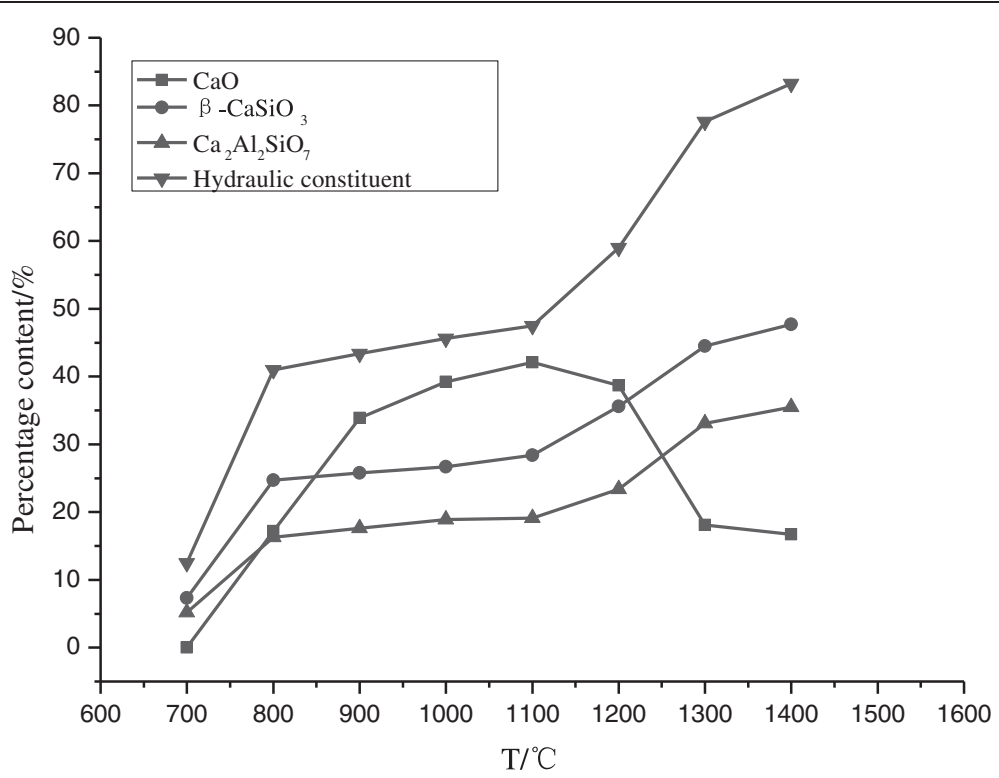

Figure 3 Change trend plots of the main products of ginger nut calcined at $700^{\circ} \mathrm{C} \sim 1400^{\circ} \mathrm{C}$ for 3 hours.

$1100^{\circ} \mathrm{C}$ to $1400^{\circ} \mathrm{C}, \mathrm{CaO}$ decreases in amount from $44.6 \%$ to $33.9 \%$, but not so obviously as ginger nut. The speed of producing $\beta-\mathrm{CaSiO}_{3}$ and $\mathrm{Ca}_{2} \mathrm{Al}_{2} \mathrm{SiO}_{7}$ increases, but it is not so quickly as ginger nut. $\beta$ $\mathrm{CaSiO}_{3}$ increases from $30.1 \%$ to $40.6 \%$ and $\mathrm{Ca}_{2} \mathrm{Al}_{2} \mathrm{SiO}_{7}$ increases from $19.2 \%$ to $25.4 \%$. The reason is the same as stated above that Aga soil has less amount of $\mathrm{SiO}_{2}$ and larger amount of $\mathrm{CaCO}_{3}$ than ginger nut.

\section{The chemical properties of calcined ginger nut and aga soil}

XRD and SEM were used to analyze ginger nut and Aga soil calcined for three hours at $1000^{\circ} \mathrm{C}$ and then

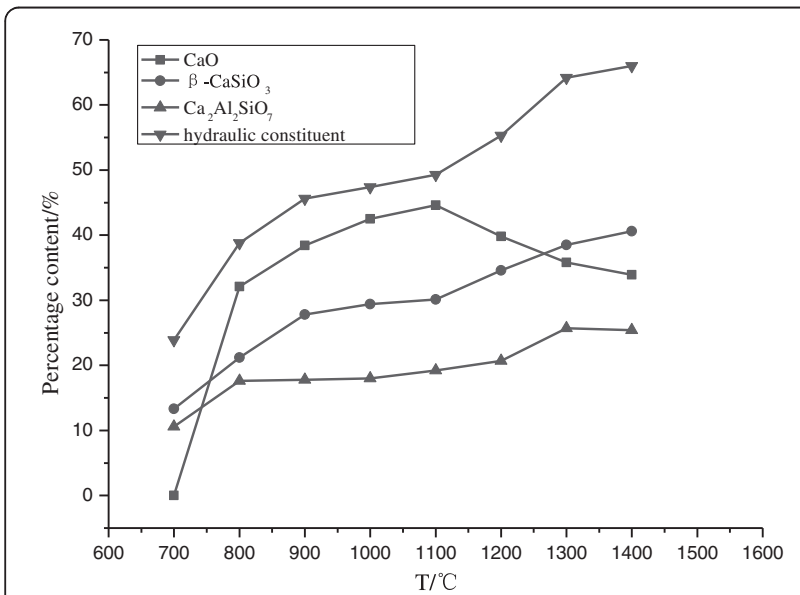

Figure 4 Change trend plots of the main products of Aga soil calcined at $700^{\circ} \mathrm{C} \sim 1400^{\circ} \mathrm{C}$ for 3 hours. analyze and study the process of their hydration and carbonization.

\section{XRD analysis}

Figures 5 and 6 are XRD spectra of calcined ginger nut and Aga soil at $1000^{\circ} \mathrm{C}$ together with their products of hydration and carbonization.

The results of XRD analysis shows the ginger nut calcined for three hours at $1000^{\circ} \mathrm{C}$ includes $39.20 \%$ $\mathrm{CaO}, \quad 26.70 \% \quad \beta-\mathrm{CaSiO}_{3}$ and $18.90 \% \quad \mathrm{Ca}_{2} \mathrm{Al}_{2} \mathrm{SiO}_{7}$ before hydration (Figure $5 \mathrm{~A}$ ). When hydrated in a relative humidity of $80 \%$, it will produce $32.6 \%$ $\mathrm{CaCO}_{3}, 22.7 \% \mathrm{Ca}(\mathrm{OH})_{2}$ and $21.6 \% \mathrm{Ca}_{2} \mathrm{Al}_{2} \mathrm{SiO}_{7} \bullet \mathrm{nH}_{2} \mathrm{O}$ (Figure 5B) after five days. After 300 days, it will produce $86.2 \% \quad \mathrm{CaCO}_{3}$ and $3.2 \% \quad \mathrm{Ca}_{2} \mathrm{Al}_{2} \mathrm{SiO}_{7} \bullet \mathrm{nH}_{2} \mathrm{O}$ (Figure $5 \mathrm{C}$ ) on the surface of samples, and at the depth of $2-3 \mathrm{~mm}$ of the samples it produces $54.6 \%$ $\mathrm{CaCO}_{3}, \quad 2.1 \% \mathrm{Ca}(\mathrm{OH})_{2}, \quad 22.6 \% \mathrm{CaSiO}_{3} \bullet \mathrm{nH}_{2} \mathrm{O}$ and 13.2\% $\mathrm{Ca}_{2} \mathrm{Al}_{2} \mathrm{SiO}_{7} \bullet \mathrm{nH}_{2} \mathrm{O}$.

When Aga soil is burned for three hours at $1000^{\circ} \mathrm{C}$, it will produce $42.50 \% \mathrm{CaO}, 29.40 \% \quad \beta-\mathrm{CaSiO}_{3}$ and $18.00 \% \mathrm{Ca}_{2} \mathrm{Al}_{2} \mathrm{SiO}_{7}$ (Figure $6 \mathrm{~A}$ ). Hydrated in $80 \%$ relative humidity, it will produce $47.6 \% \mathrm{CaCO}_{3}, 13.1 \% \mathrm{Ca}$ $(\mathrm{OH})_{2}$ and16.7\% $\mathrm{Ca}_{2} \mathrm{Al}_{2} \mathrm{SiO}_{7} \bullet \mathrm{nH}_{2} \mathrm{O}$ (Figure 6B) after five days. Three hundred days later, on the surface of the samples is produced $74.2 \% \mathrm{CaCO}_{3}$, and at the depth of $2-3 \mathrm{~mm}$ produced $48.4 \% \mathrm{CaCO}_{3}, 24.6 \% \mathrm{Ca}(\mathrm{OH})_{2}$, $5.3 \% \beta-\mathrm{CaSiO}_{3} \cdot \mathrm{nH}_{2} \mathrm{O}$.

XRD semi-quantitative analysis verifies that after being calcined for three hours at $1000^{\circ} \mathrm{C}$, ginger nut and Aga soil a $80 \%$ relative humidity have large speeds of hydration and carbonization. Five days 


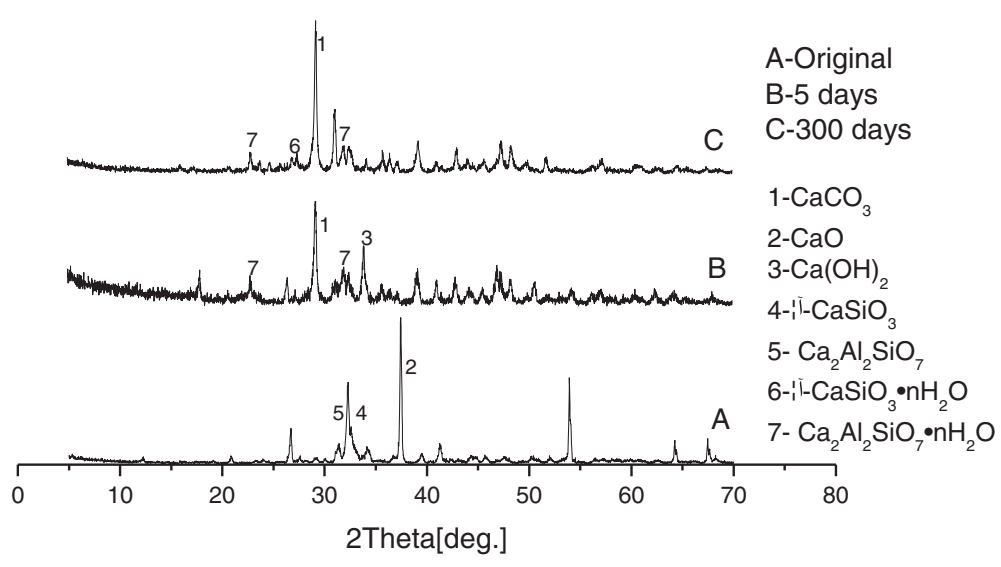

Figure 5 Comparative XRD spectra of calcined ginger nut at $1000^{\circ} \mathrm{C}$ after 5 days' hydration and 300 days' hydration $\left(1-\mathrm{CaCO}_{3} ; 2-\mathrm{CaO}^{\prime}\right.$ $\left.3-\mathrm{Ca}(\mathrm{OH})_{2} ; 4-\beta-\mathrm{CaSiO}_{3} ; 5-\mathrm{Ca}_{2} \mathrm{Al}_{2} \mathrm{SiO}_{7} ; 6-\beta-\mathrm{CaSiO}_{3} \cdot \mathrm{nH}_{2} \mathrm{O} ; 7-\mathrm{Ca}_{2} \mathrm{Al}_{2} \mathrm{SiO}_{7} \cdot \mathrm{nH}_{2} \mathrm{O}\right)$.

later, they respectively produce $32.6 \%$ and $47.6 \%$ $\mathrm{CaCO}_{3}, 22.7 \%$ and $13.1 \% \mathrm{Ca}(\mathrm{OH})_{2}$ and $21.6 \%$ and $16.7 \% \mathrm{Ca}_{2} \mathrm{Al}_{2} \mathrm{SiO}_{7} \bullet \mathrm{nH}_{2} \mathrm{O}$. Three hundred days later, calcined ginger nut and Aga soil samples have a $3 \mathrm{~mm}$ depth of carbonized layer and produce $86.2 \%$ and $74.2 \% \mathrm{CaCO}_{3}$ respectively. At $3 \mathrm{~mm}$ depth, it generates $54.6 \%$ and $48.4 \% \mathrm{CaCO}_{3}$. Calcined ginger nut is carbonized more quickly than Aga soil.

\section{SEM-EDS analysis}

Figures 7 to 11 are SEM photos and EDS spectra of burned ginger nut and Aga soil and their products of hydration and carbonization.

SEM photos show that ginger nut and Aga soil calcined for three hours at $1000^{\circ} \mathrm{C}$ produce fine crystal aggregates of $\mathrm{CaO}, \beta-\mathrm{CaSiO}_{3}$ and $\mathrm{Ca}_{2} \mathrm{Al}_{2} \mathrm{SiO}_{7}$ (Figure $7 \mathrm{a}$ and $\mathrm{b}$ ). Five days later after hydration, the sample of calcined ginger nut produces little re-crystals $\mathrm{CaCO}_{3}$ and crystal aggregates $\beta-\mathrm{CaSiO}_{3}$ and $\mathrm{Ca}_{2} \mathrm{Al}_{2} \mathrm{SiO}_{7}$. On the surface of calcined Aga soil, re-crystals $\mathrm{CaCO}_{3}$ is produced (Figures $8 \mathrm{a}$ and 10a). and at the deep layer, the calcined ginger nut produces little crystals $\beta-\mathrm{CaSiO}_{3}$. $n \mathrm{H}_{2} \mathrm{O}$ and $\mathrm{Ca}_{2} \mathrm{Al}_{2} \mathrm{SiO}_{7} \cdot \mathrm{nH}_{2} \mathrm{O}$ encircled by large quartz particles. The deep layer of Aga sample produces little re-crystals $\mathrm{CaCO}_{3}$, crystals $\beta-\mathrm{CaSiO}_{3} \cdot \mathrm{nH}_{2} \mathrm{O}$ and $\mathrm{Ca}_{2} \mathrm{Al}_{2} \mathrm{SiO}_{7} \cdot \mathrm{nH}_{2} \mathrm{O}$ (Figures $8 \mathrm{~b}$ and $10 \mathrm{~b}$ ). Three hundred days later after hydration, both of calcined ginger nut and Aga soil on the surface form a lot of compact recrystals $\mathrm{CaCO}_{3}$ (Figures 9a and 11a), and at their deep level it forms little re-crystals $\mathrm{CaCO}_{3}$ and a lot of crystals $\beta-\mathrm{CaSiO}_{3} \cdot \mathrm{nH}_{2} \mathrm{O}$ and $\mathrm{Ca}_{2} \mathrm{Al}_{2} \mathrm{SiO}_{7} \cdot \mathrm{nH}_{2} \mathrm{O}$ (Figures $9 \mathrm{~b}$ and $11 \mathrm{~b}$ ). Moreover, in the process of hydration $\mathrm{Ca}$ $(\mathrm{OH})_{2}$ will be produced, and it will gradually adsorb $\mathrm{CO}_{2}$ generate $\mathrm{CaCO}_{3}$.

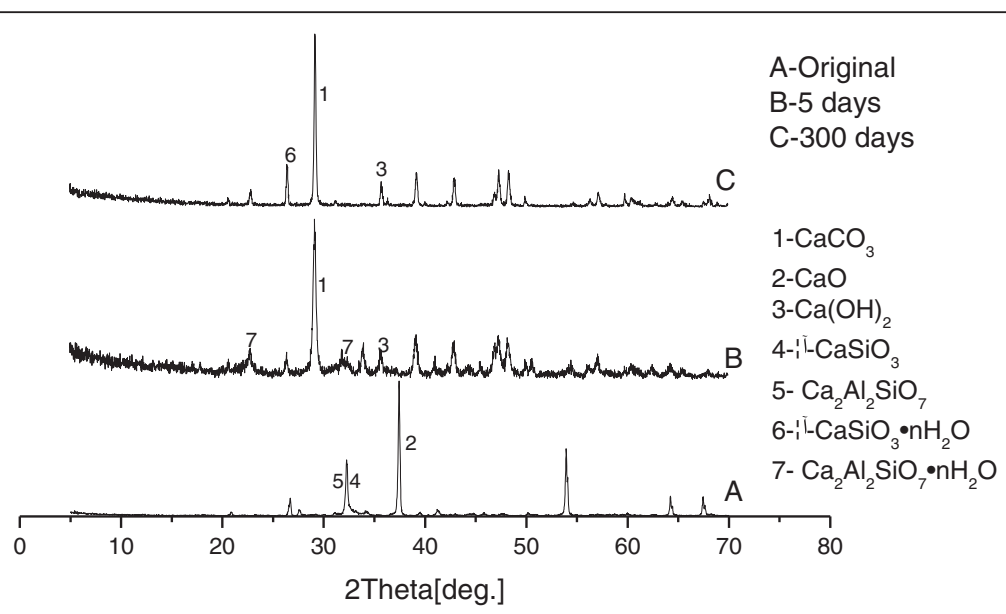

Figure 6 Comparative XRD spectra of calcined Aga soil at $1000^{\circ} \mathrm{C}$ after 5 day' hydration and 300 days' hydration $\left(1-\mathrm{CaCO}_{3} ; 2-\mathrm{CaO}^{\prime}\right.$ $\left.3-\mathrm{Ca}(\mathrm{OH})_{2} ; 4-\beta-\mathrm{CaSiO}_{3} ; 5-\mathrm{Ca}_{2} \mathrm{Al}_{2} \mathrm{SiO}_{7} ; 6-\beta-\mathrm{CaSiO}_{3} \cdot \mathrm{nH}_{2} \mathrm{O} ; 7-\mathrm{Ca}_{2} \mathrm{Al}_{2} \mathrm{SiO}_{7} \cdot \mathrm{nH}_{2} \mathrm{O}\right)$. 


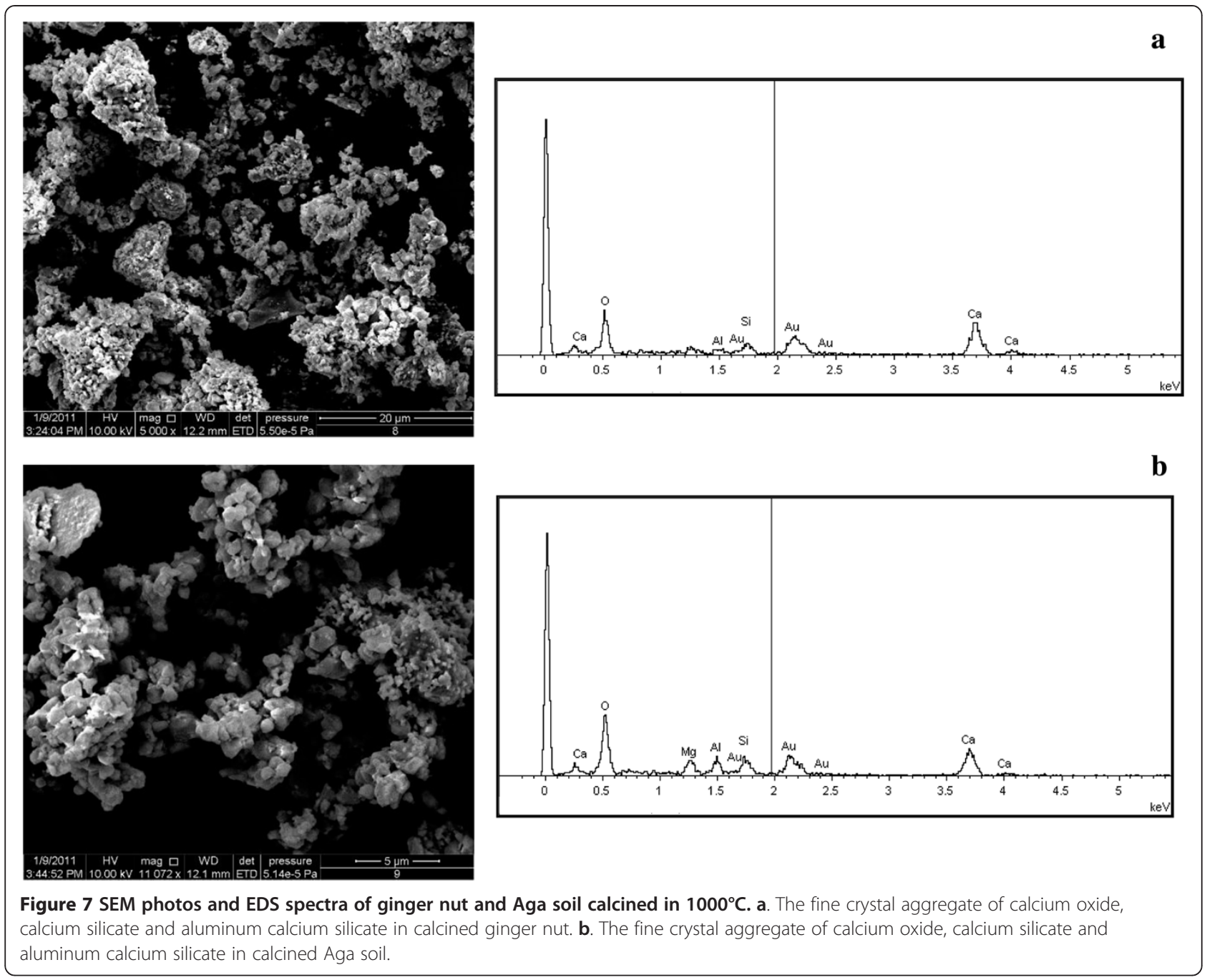

\section{Discussion}

More than five thousand years ago in China, calcined ginger nut had been used as building material for building floors during the Yangshao Period. In Tibet, Aga soil had been used as a building material of temple floors and roofs for over one thousand years. Ginger nut can be also called clay limestone and Aga soil called silicious limestone. The contents of clay and $\mathrm{SiO}_{2}$ in ginger nut and Aga soil differ from those from different regions. But whatever the contents of clay and $\mathrm{SiO}_{2}$ in them, the raw ginger nut and Aga soil will not produce the binding materials and are not suitable for being used as building materials without being calcined. The percentages of silicon and clay in ginger nut and Aga soil decide the contents of non-hydraulicity and hydraulicity in the binding materials produced by high temperature calcination and also influence the properties of ginger nut and Aga soil calcined at different temperatures.
The above research proves that ginger nut from Qin'an Dadiwan of Gansu and Aga soil from Shan'nan in Tibet are calcined for three hours at eight temperatures from $700^{\circ} \mathrm{C}$ to $1400^{\circ} \mathrm{C}$, and their products non-hydraulic material $\mathrm{CaO}$ and hydraulic materials $\beta-\mathrm{CaSiO}_{3}$ and $\mathrm{Ca}_{2} \mathrm{Al}_{2} \mathrm{SiO}_{7}$ change regularly in ratio. Their properties differ slightly because of their different ratios. For example, if there are much larger hydraulic components, the strength of materials grows faster at early stage and it will combine with the body of cultural relics repaired. But the main defect is the low porosity of cementitious materials formed, thus the material show bad air and water permeabilities. Influenced by temperature and humidity, the repairing materials will detach from the body of the restored relics in a short period (generally 3 to 5 years). So this material has bad durability. If the nonhydraulic components increase a little more, the strength of materials will grow slowly, and the repairing 

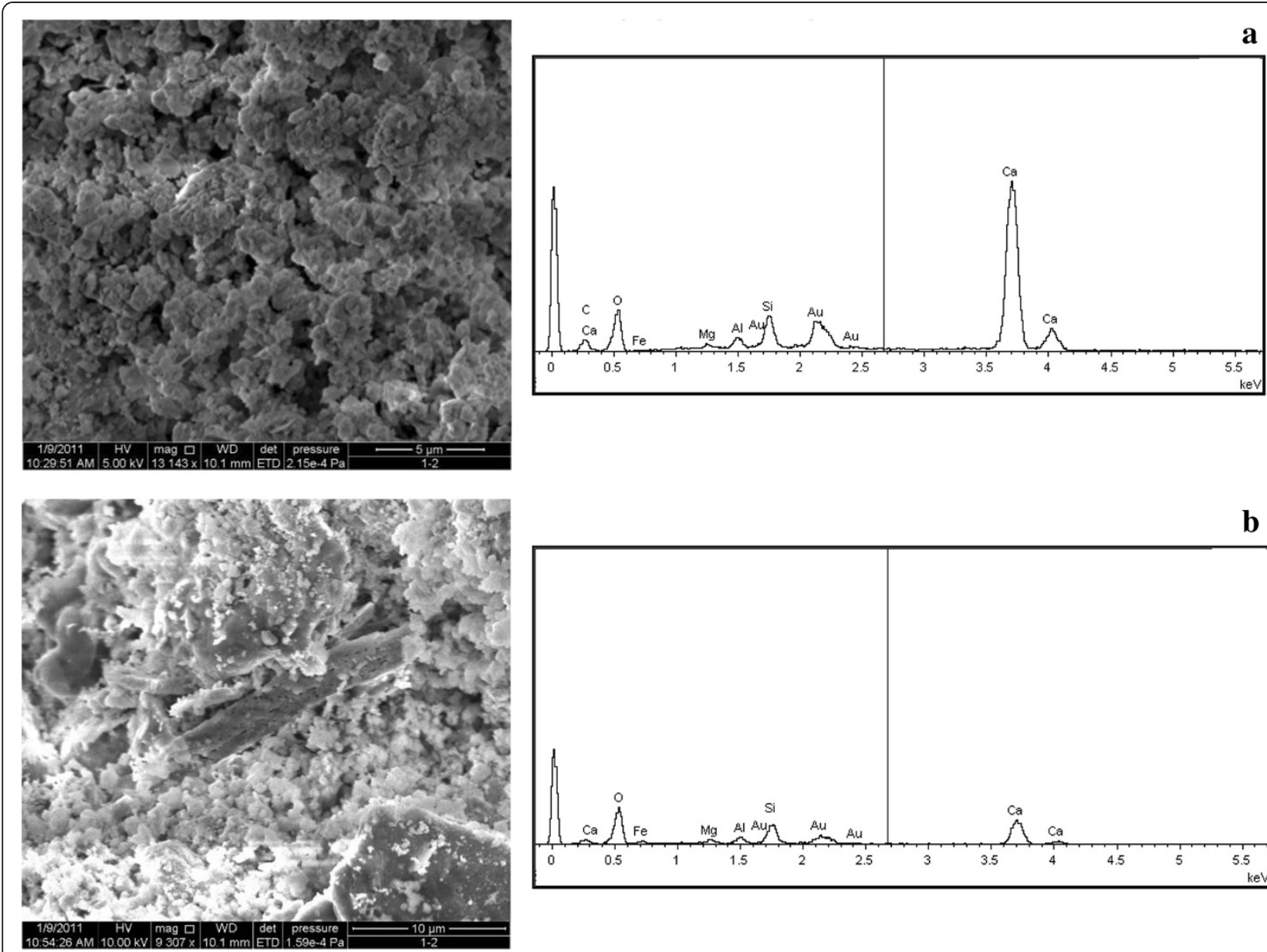

Figure $8 \mathrm{SEM}$ photos and EDS spectra of ginger calcined in $1000^{\circ} \mathrm{C}$ after hydration and carbonization for five days. a. The forming of minor calcium carbonate re-crystalline on the surface, and the aggregate with calcium silicate and aluminum calcium silicate crystal. b. The forming of minor hydrated calcium silicate in the deep layer, and the crystal of hydrated aluminum calcium silicate covering big quartz particles.

material can't combine with the relics in a short time and thus affect the results of restoration.

Calcined ginger nut and Aga soil have a key characteristic in repairing stone relics, namely $\mathrm{CaO}$ will combine with water to generate gel $\mathrm{Ca}(\mathrm{OH})_{2}$, which then reacts with $\mathrm{CO}_{2}$ and $\mathrm{H}_{2} \mathrm{O}$ in the air to gradually produce large porosity gel $\mathrm{CaCO}_{3}$. This process is called self-repairing effect of hydraulic limestone [8-14] by European scholars. Although the carbonization of non-hydraulic constitute is slow, the whole process of carbonization begins from the surface and extends in depth. When relative humidity in the environment is $80 \%$, the hydration and carbonization will be fast on the surface and then become slowly in the depth because $\mathrm{CO}_{2}$ is much less. Just because of this, $\mathrm{CaCO}_{3}$, the gel with big porosity and good water permeability, will be produced during the slow carbonization process. The $\mathrm{CaCO}_{3}$ produced from fast carbonization on the surface is complementary to the strength of the $\beta-\mathrm{CaSiO}_{3} \cdot \mathrm{nH}_{2} \mathrm{O}$ and
$\mathrm{Ca}_{2} \mathrm{Al}_{2} \mathrm{SiO}_{7} \cdot \mathrm{nH}_{2} \mathrm{O}$ produced from fast hydration of hydraulic constitute sand therefore can meet the requirements for relics restoration. Then the gradual carbonization of this gel will make it tightly combined with the relics, creating good weathering resistance. Conservators in Europe had found the advantages of the binding material (hydraulic lime) calcined by clay limestone and siliceous limestone in the restoration of stone relics. In 1970s, they had used binding materials similar to Chinese ancient calcined ginger nut in the restoration of stone relics and obtained good conservation results [15-23]. They pointed out that hydraulic lime stone "has specific usefulness that can't be replaced by concrete and non-hydraulic limestone particularly in the restoration of ancient or old buildings" [24].

Calcined ginger nut had been used as the biding materials in the building floors of the Dadiwan site in Gansu Qin'an during the Yangshao Period. No matter what 

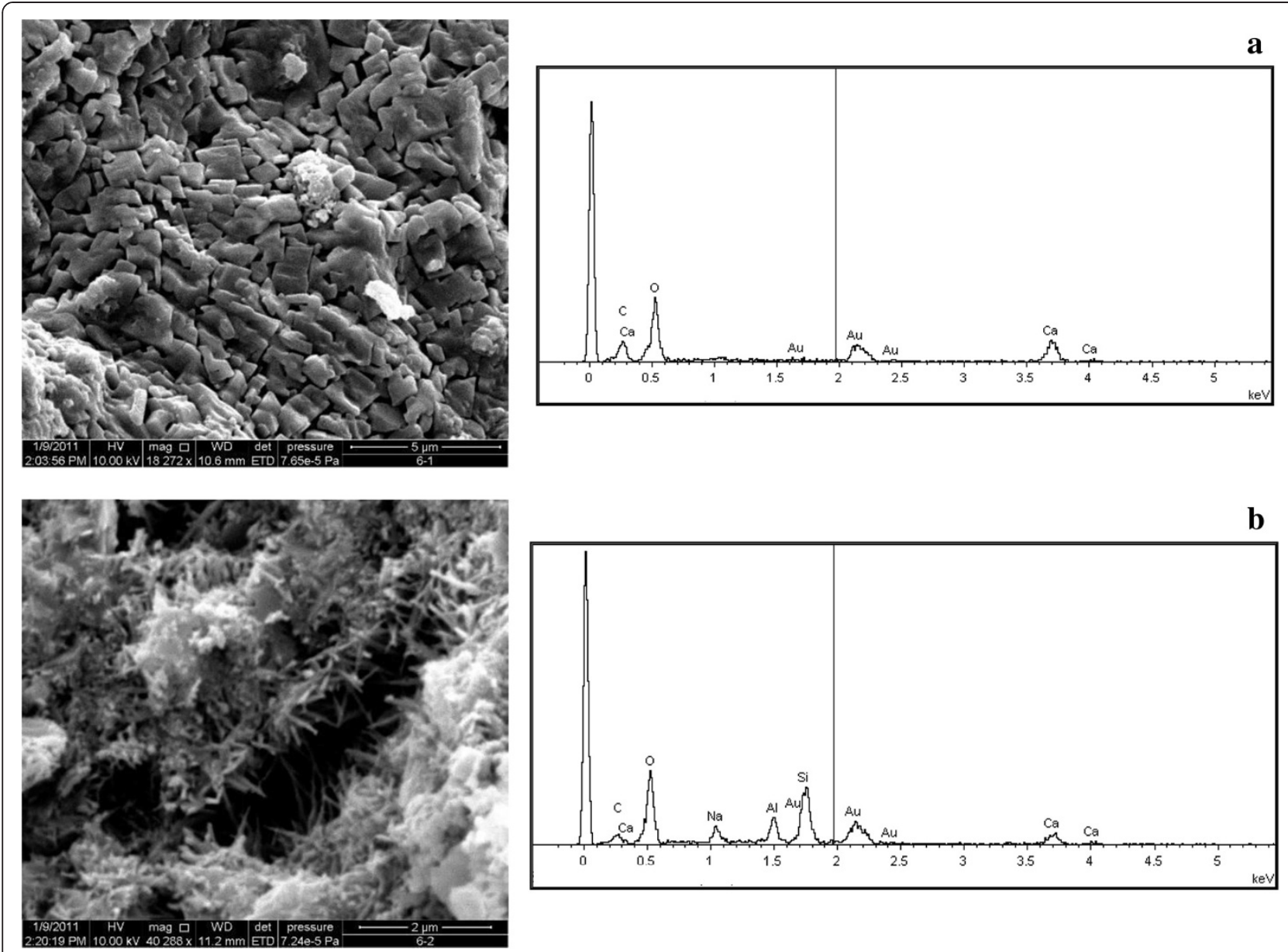

Figure $9 \mathrm{SEM}$ photos and EDS spectra of ginger calcined in $1000^{\circ} \mathrm{C}$ after hydration and carbonization for 300 days. a. The forming of a large number of compact calcium carbonate re-crystalline on the surface; $\mathbf{b}$. The forming of minor calcium carbonate re-crystalline and a large number of hydrated calcium silicate and hydrated aluminum calcium silicate crystal in the deep layer.

percentage of $\mathrm{CaO}, \beta-\mathrm{CaSiO}_{3}$ and $\mathrm{Ca}_{2} \mathrm{Al}_{2} \mathrm{SiO}_{7}$ was in calcined ginger nut, for thousands of years, the site of housing was buried under loess of farm land of hillside. Non-hydraulic and hydraulic materials mainly changed into porous $\mathrm{CaCO}_{3}$ through their interaction with $\mathrm{CO}_{2}$ and $\mathrm{H}_{2} \mathrm{O}$. So after more than five thousand years, F-901 floor material at Dadiwan is similar to modern No. 100 cement mortar floor in compressive strength. However for centuries, the Aga soil used in Tibetan building floors and roofs was never burned at high temperature. This material didn't include non-hydraulic binding material and hydraulic material, thus this building material had low strength and poor weathering resistance. The roofs of temples have to be restored once in three to five years, not only involving a lot of work and time, and but also increasing cost and damages. Preliminary tests demonstrate the floor and roof material added with powder of $30 \%$ calcined Aga soil as binding material can obviously improve the strength and weathering resistance of materials.

\section{Conclusion}

The following conclusions can be reached through the above tests and discussion:

(1) By controlling the calcining temperature and selecting ginger nut and Aga soil with proper amounts of clay and $\mathrm{SiO}_{2}$, binding materials which contain non-hydraulic material $\mathrm{CaO}$ and hydraulic materials $\beta-\mathrm{CaSiO}_{3}$ and $\mathrm{Ca}_{2} \mathrm{Al}_{2} \mathrm{SiO}_{7}$ in various ratios can be made.

(2) The ginger nut from Qin'an in Gansu will produce about $39.2 \% \mathrm{CaO}, 45.6 \% \beta-\mathrm{CaSiO}_{3}$ and $\mathrm{Ca}_{2} \mathrm{Al}_{2} \mathrm{SiO}_{7}$ if calcined for three hours at $1000^{\circ} \mathrm{C}$, while the Aga soil in Tibetan Shan'nan will produce about $42.5 \%$ $\mathrm{CaO}, 47.4 \% \beta-\mathrm{CaSiO}_{3}$ and $\mathrm{Ca}_{2} \mathrm{Al}_{2} \mathrm{SiO}_{7}$ after being calcined for three hours at $1000^{\circ} \mathrm{C}$. 


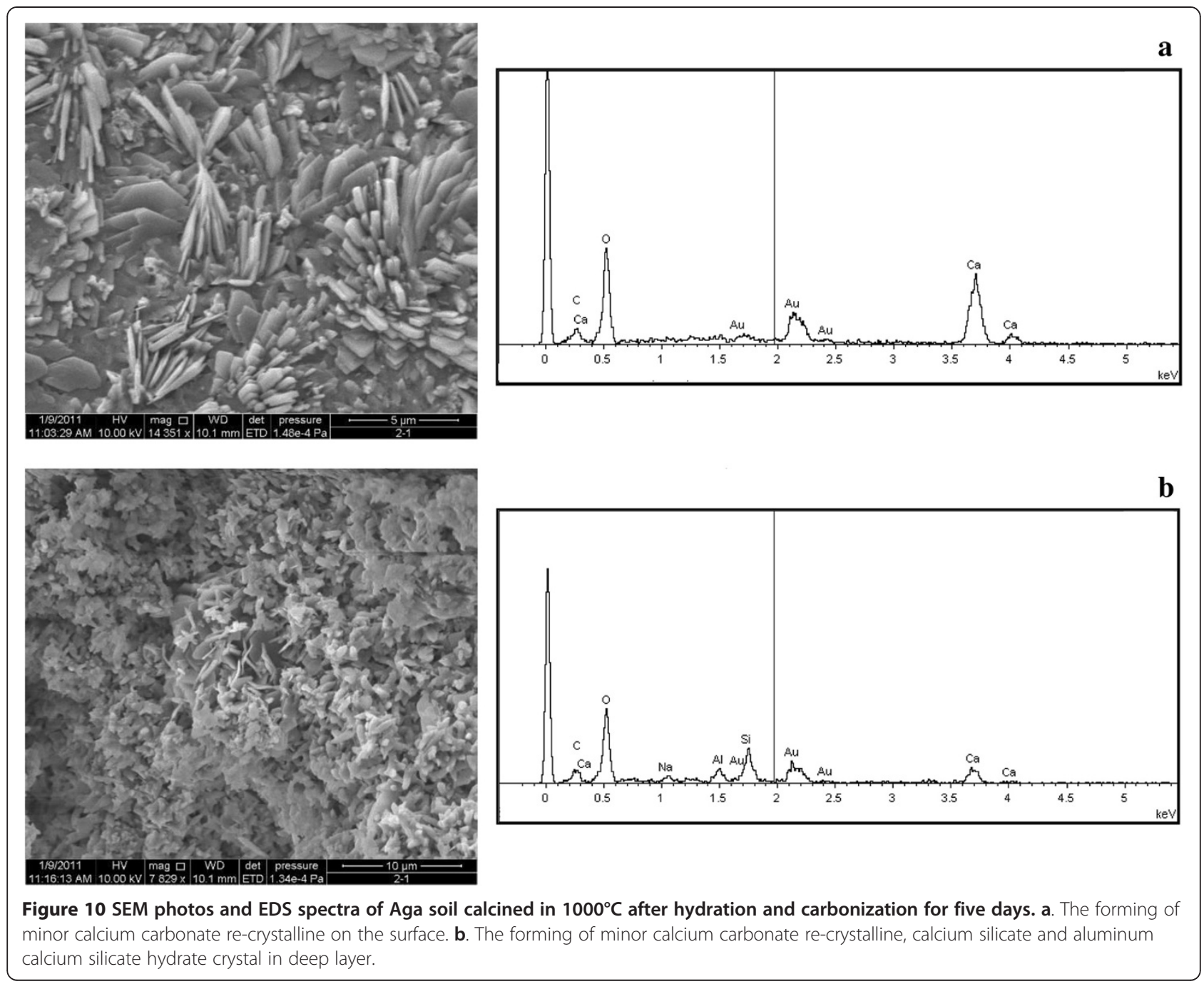

(3) As calcining temperature rises $\left(700^{\circ} \mathrm{C} \sim 1400^{\circ} \mathrm{C}\right)$, non-hydraulic constitutes will reach the peak point at $1100^{\circ} \mathrm{C}$ and then drop to the bottom point at $1400^{\circ} \mathrm{C}$, and hydraulic constitutes will keep rising to the peak point at $1400^{\circ} \mathrm{C}$.

(4) Calcined ginger nut and Aga soil in the environment of $80 \%$ relative humidity have a faster speed of hydration and carbonization. After five days' hydration, calcined ginger nut will produce $32.6 \%$ $\mathrm{CaCO}_{3}$ and 21.6\% $\mathrm{Ca}_{2} \mathrm{Al}_{2} \mathrm{SiO}_{7} \cdot \mathrm{nH}_{2} \mathrm{O}$; while calcined Aga soil will produces $47.6 \% \mathrm{CaCO}_{3}$ and $16.7 \%$ $\mathrm{Ca}_{2} \mathrm{Al}_{2} \mathrm{SiO}_{7} \cdot \mathrm{nH}_{2} \mathrm{O}$. Three hundred days later after hydration and carbonization, the thickness of carbonization on sample surface reaches $3 \mathrm{~mm}$ with $80 \% \mathrm{CaCO}_{3}$ produced. Even under the depth of $3 \mathrm{~mm}$, it also produces $50 \% \mathrm{CaCO}_{3}, 34 \% \beta-\mathrm{CaSiO}_{3}$. $\mathrm{nH}_{2} \mathrm{O}$ and $\mathrm{Ca}_{2} \mathrm{Al}_{2} \mathrm{SiO}_{7} \cdot \mathrm{nH}_{2} \mathrm{O}$.

(5) Controling the ratio of non-hydraulic constitutes $\mathrm{CaO}$, hydraulic constitutes $\beta-\mathrm{CaSiO}_{3}$ and $\mathrm{Ca}_{2} \mathrm{Al}_{2} \mathrm{SiO}_{7}$ in binding materials can not only adjust its early strength but also form the calculus of large porosity, good weathering resistance and high strength in the process of slow 'carbonization' that will firmly integrate with the stone relics and meet the requirements of conservation and consolidation of cultural relics.

\section{Competing interests}

The authors declare that they have no competing interests.

\section{Authors' contributions}

The work presented here was carried out in collaboration between all authors. $L Z$ and $Z L$ defined the research theme. $L Z, Z L$, $L L$ and WJ designed methods and experiments, carried out the laboratory experiments, analyzed the data, interpreted the results and wrote the paper. All authors have contributed to, seen and approved the manuscript.

\section{Author details}

${ }^{1}$ National Research Center for Conservation of Ancient Wall Paintings, Dunhuang 736200, China. ${ }^{2}$ Chinese Academy of Cultural Heritage, Beijing 100871, China. ${ }^{3}$ Dunhuang Academy, Dunhuang 736200, China. 

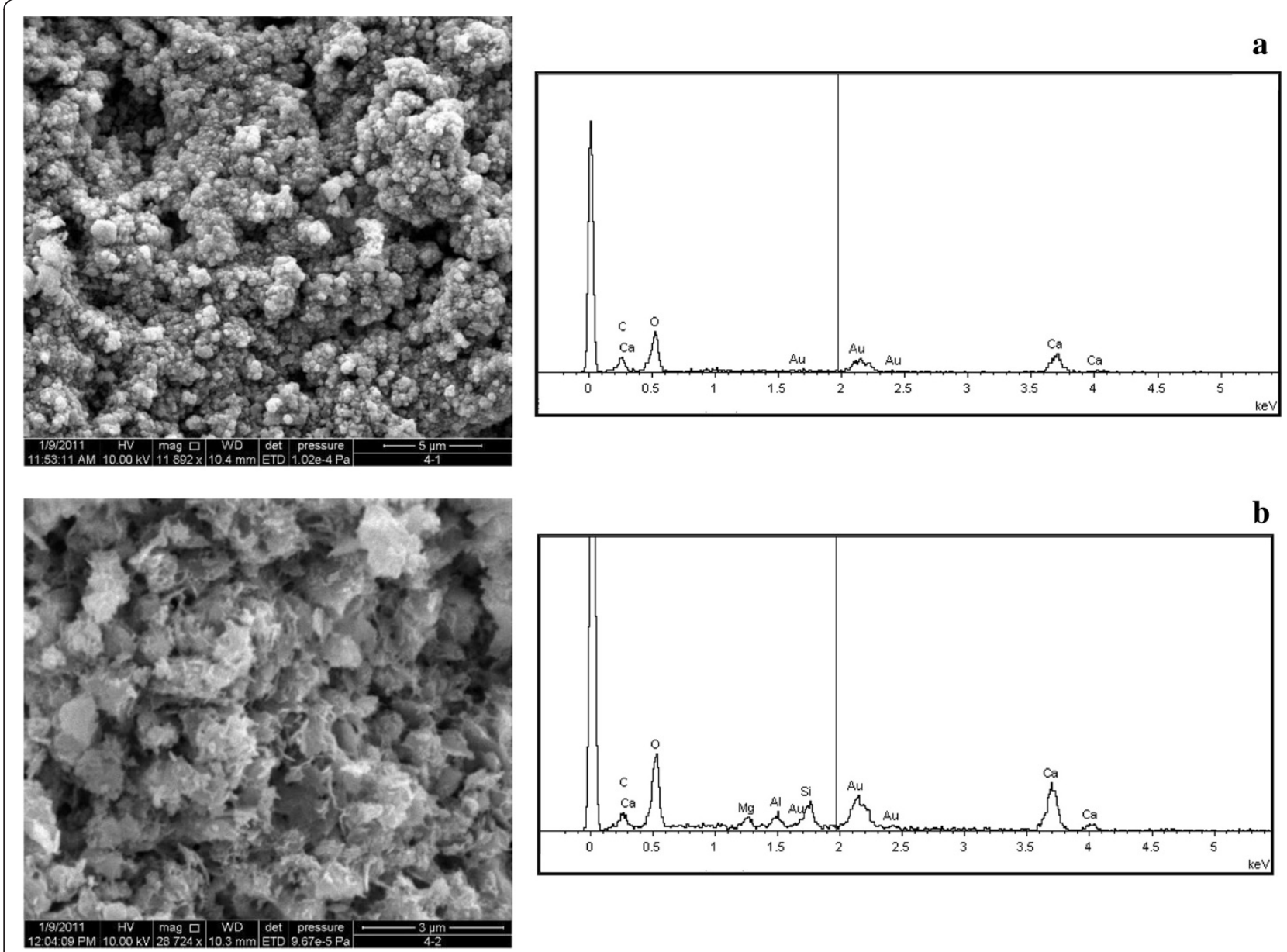

Figure $11 \mathrm{SEM}$ photos and EDS spectra of Aga soil calcined in $1000^{\circ} \mathrm{C}$ after hydration and carbonization for 300 days. a. The forming of a large number of calcium carbonate re-crystalline on the surface. $\mathbf{b}$. The forming of minor calcium carbonate re-crystalline, and a large number of hydrated calcium silicate and hydrated aluminum calcium silicate crystal in the deep layer.

\section{References}

1. Gansu Province Cultural Relics Institute of Archaeology: Archaeological excavation reports on New stone Age of dadiwan site of Qin'an(in Chinese) (top, down volume). Beijing: Cultural Relics Press; 2006.

2. Cultural Relic Work Team of Gansu Museum: 405\# New stone age housing site of dadiwan site of Qin'an (in Chinese). Cult Rel 1983(11):15-20

3. Li ZX: Wonder work of ancient building history of china (in Chinese). Archaeology 1985(8):741-747.

4. Li ZX: The most ancient concrete in the world (in Chinese). Archaeology 1988, 8:751-756.

5. Li ZX, Wang WF, Wang XD, et al: Project report of the conservation and restoration of Tibetan potala Palace's murals(in Chinese). Beijing: Cultural Relics Press; 2008.

6. Li YX: A talk of Aga soil. China's Tibet 1995(1):33.

7. Jiang HY, Ge S, Penjor Ron J, Wang M: Project report of the restoration of Tibetan potala palace(in Chinese). Beijing: Cultural Relics Press; 1994.

8. Moropoulou A, Biscontin G, Bakolas A, Bisbikou K: Technology and behavior of rubble masonry. Constr Build Mater 1997, 11(2):119-129.

9. Hughes JJ, Hughes JJ, Cuthbert SJ: The petrography and microstructure of medieval lime mortars from the west of Scotland: Implications for the formulation of repair and replacement mortars. Mater Struct 2000, 33(11):594-600.

10. Maravelaki-Kalaitzakia P, Bakolasb A, et al: Hydraulic lime mortars for the restoration of historic masonry in Crete. Cem Concr Res 2005, 35(8):1577-1586.
11. Lawrence RMH, Mays TJ, Walker P, et al: The use of TG to measure different concentrations of lime in non-hydraulic lime mortars. J Therm Anal Calorim 2006, 85(2):377-382.

12. Hanley R, Pavía S: A study of the workability of natural hydraulic lime mortars and its influence on strength. Mater Struct 2008, 41(2):373-381.

13. El-Turki A, Ball RJ, Carter MA, et al: Effect of dewatering on the strength of lime and cement mortars. J Am Ceram Soc 2010, 93(7):2074-2081.

14. Victoria I, Pingarrón A: Performance analysis of hydraulic lime grouts for masonry repair. Presented to the faculties of the University of Pennsylvania in partial fulfillment of the requirements for the degree of master of science in historic preservation. 2006

15. Moropoulou A, Bakolas A, Bisbikou K: Physico-chemical adhesion and cohesion bonds in joint mortars imparting durability to the historic structures. Constr. Build. Mater. 2000, 14(1):35-46.

16. Moropoulou A, Bakolas A, Bisbikou K: Investigation of the technology of historic mortars. J Cult Herit 2000, 1(1):45-58.

17. Sabbioni C, Zappia G, Riontino C, et al: Atmospheric deterioration of ancient and modern hydraulic mortars. Atmos Environ 2001, 35(3):539-548.

18. Sabbioni C, Bonaza A, Zappia G: Damage on hydraulic mortars: the venice arsenal. J Cult Herit 2002, 3(1):83-88.

19. Biscontin G, Birelli MP, Zendri E: Characterization of binders employed in the manufacture of Venetian historical mortars. J Cult Herit 2002, 3(1):31-37.

20. Fasssina V, Favaro M, Naccari A, et al: Evaluation of compatibility and durability of a hydraulic lime-based plasters applied on brick wall 
masonry of historical buildings affected by rising damp phenomena. J Cult Herit 2002, 3(1):45-51.

21. Mosquera MJ, Benitez D, Perry SH: Pore structure in mortars applied on restoration. Effect on properties relevant to decay of granite buildings. Cem Concr Res 2002, 32(12):1883-1888.

22. Lanas J, Pérez Bernal JL, Bello MA, et al: Mechanical properties of natural hydraulic lime-based mortars. Cem Concr Res 2004, 34(12):2191-2201.

23. Pavía S, Toomey B: Influence of the aggregate quality on the physical properties of natural feebly-hydraulic lime mortars. Mater Struct 2008, 41(3):559-569.

24. Peng FS: Natural hydraulic lime. lime(in Chinese) 2009(3):44-48.

doi:10.1186/2050-7445-1-27

Cite this article as: Zuixiong et al:: Research on the modification of two traditional building materials in ancient China. Heritage Science 2013 1:27.

\section{Publish with ChemistryCentral and every scientist can read your work free of charge \\ "Open access provides opportunities to our colleagues in other parts of the globe, by allowing anyone to view the content free of charge." \\ W. Jeffery Hurst, The Hershey Company. \\ - available free of charge to the entire scientific community \\ - peer reviewed and published immediately upon acceptance \\ - cited in PubMed and archived on PubMed Central \\ - yours - you keep the copyright \\ Submit your manuscript here: \\ http://www.chemistrycentral.com/manuscript/<smiles>c1ccccc1</smiles> 